\title{
Relationship between Physical Activity of Pregnant Women in the Third Trimester of Pregnancy with Preterm Birth Using Kaiser Physical Activity Survey (KPAS) Questionnaire
}

\author{
Hubungan antara Aktivitas Fisik Perempuan Hamil pada Trimester Ketiga \\ Kehamilan dengan Persalinan Prematur Menggunakan Kuesioner \\ Kaiser Physical Activity Survey (KPAS)
}

\author{
JM Seno Adjie, AA Rai D Maharani \\ Department of Obstetrics and Gynecology \\ Faculty of Medicine Universitas Indonesia/ \\ Dr. Cipto Mangunkusumo Hospital
}

Jakarta

\begin{abstract}
Objective: To examine the relationship between the intensity of physical activity of pregnant women with preterm birth and to know the relationship between types of physical activity of pregnant women with preterm birth.
\end{abstract}

Methods: This research was a case-control study that was conducted at Dr. Cipto Magunkusumo Hospital and Karawang Hospital in January 2017 to June 2017 with KPAS questionnaire which was divided into two groups, preterm birth and term birth. The sample size was 127 subjects for each group. The analysis was done by multivariate analysis of the etiologic concept.

Results: In term birth, the most frequent physical activity intensities were: moderate intensity $(64.6 \%, n=82)$, light intensity $(22 \%, n=$ $28)$, and vigorous intensity $(13.4 \%, \mathrm{n}=17)$. In preterm birth, the most frequent physical activity intensities were: light intensity $(40.1 \%, n=51)$, vigorous intensity $(33.9 \%, n=43)$, and moderate intensity $(26 \%, \mathrm{n}=33)$. Adjusted OR of preterm birth in light intensity versus moderate intensity was OR 5.32 (95\% CI, 2.80-10.13; $\mathrm{p}=$ $<0.001$ ). While adjusted OR of preterm birth in vigorous intensity compared with moderate intensity was OR 6.29 (95\% CI, 3.2813.46; $\mathrm{p}=<0.001$ ). Work and sport have a significant association with preterm birth with OR $3.19(95 \% \mathrm{CI}, 1.62-6.28$; $\mathrm{p}=0.001)$ and OR 1.85 (95\% CI,1.11 - 3.09; p= 0.017). Occupational conditions are also associated with preterm birth, including: weight lifting with OR 5.16 (95\% CI, 1.10-24.08, $\mathrm{p}=0.021$ ), walking with OR 3.57 (95\% CI, 1.61-7.92, $\mathrm{p}=0.001)$, sitting with OR 2.79 (95\% CI, 1.23-6.31, $\mathrm{p}=$ 0.011), and standing with OR 3.04 (95\% CI, 1.40-6.59; $\mathrm{p}=0.003)$.

Conclusion: There is a significant relationship between the intensity of physical activity and type of physical activity in pregnant women with preterm birth.

[Indones J Obstet Gynecol 2018; 6-4: 203-208]

Keywords: intensity of physical activity, KPAS, physical activity, preterm labour

\begin{abstract}
Abstrak
Tujuan: Mengetahui hubungan antara intensitas aktivitas fisik perempuan hamil dengan persalinan prematur dan mengetahui hubungan antara jenis aktivitas fisik perempuan hamil dengan persalinan prematur.

Metode: Penelitian ini merupakan penelitian kasus kontrol yang dilakukan di RS Dr. Cipto Magunkusumo dan RS Karawang pada bulan Januari 2017 hingga Juni 2017 dengan kuesioner KPAS yang dikelompokkan menjadi dua, yaitu persalinan prematur dan persalinan cukup bulan. Jumlah sampel adalah 127 subjek untuk masing-masing kelompok. Analisis dilakukan dengan analisis multivariat konsep etiologik.

Hasil: Pada persalinan cukup bulan, secara berurutan intensitas aktivitas fisik yang paling banyak dilakukan, antara lain : intensitas sedang $(64,6 \%, n=82)$, intensitas ringan $(22 \%, n=28)$, dan intensitas berat $(13,4 \%, n=17)$. Pada persalinan prematur, secara berurutan intensitas aktivitas fisik yang paling banyak dilakukan, antara lain: intensitas ringan $(40,1 \%, n=51)$, intensitas berat (33,9\%, $n=43)$, dan intensitas sedang $(26 \%, n=33)$. Hubungan antara intensitas aktivitas fisik ringan dibandingkan intensitas sedang untuk persalinan prematur memiliki OR 5,32 (IK 95\% 2,80-10,13; $p=<0,001$ ). Sedangkan hubungan antara intensitas aktivitas fisik berat dibandingkan intensitas sedang untuk persalinan prematur memiliki OR 6,29 (IK 95\% 3,28-13,46; $p=<0,001)$. Pekerjaan dan olahraga memiliki hubungan bermakna dengan persalinan prematur dengan OR 3,19 (IK 95\% 1,62 - 6,28; $p=0,001)$ dan OR 1,85 (IK 95\% 1,11 - 3,09; $p=0,017)$. Kondisi pekerjaan juga berhubungan dengan persalinan prematur, antara lain : angkat berat (OR 5,16; IK 95\% 1,10-24,08; $p=0,021$ ), berjalan (OR 3,57; IK 95\% 1,61-7,92; $p=0,001$ ), duduk (OR 2,79; IK 95\% 1,236,31; $p=0,011$ ), dan berdiri (OR 3,04; IK 95\% 1,40-6,59; $p=0,003$ ).

Kesimpulan: Terdapat hubungan yang bermakna antara intensitas aktivitas fisik dan jenis aktivitas fisik pada perempuan hamil dengan persalinan prematur.
\end{abstract}

[Maj Obstet Ginekol Indones 2018; 6-4: 203-208]

Kata kunci: aktivitas fisik, intensitas aktivitas fisik, KPAS, persalinan prematur 


\section{INTRODUCTION}

Preterm birth has become a global problem, and over $60 \%$ of preterm birth occur in Africa and South Asia. Currently, Indonesia is in the fifth rank after India, China, Nigeria, and Pakistan. ${ }^{1,2}$ In Indonesia, preterm birth is a national problem that causes neonatal deaths more than $70 \%$ without congenital abnormalities, and until this time, preterm birth is still being the first cause of neonatal death. ${ }^{1,2}$ Now, physical activity start to become a consideration as a risk factor of preterm birth due to its capability to be modified. The hypothesis that physical activity can lead to preterm birth is from the change in blood flow at the time of physical activity which causes the disturbance of $02, \mathrm{CO} 2$, and transplacental nutrients transport thus increasing the risk of preterm birth. ${ }^{3-7}$ However, in other studies it was found that exercise would stimulate placenta cell proliferation and increase the volume of vascular villi, thereby increasing the transfer of oxygen and nutrients through the placenta and the baby. ${ }^{8,9}$ Study on the relationship between types of physical activity with preterm birth has been widely done. Physical activity in women includes household activities, occupation, active living habits, and exercise. To date, there are only a few studies about the relationship between the total physical activity of pregnant women with preterm birth and it still could not be concluded whether there was a relationship between physical activity and preterm birth. ${ }^{4,10}$ One cause that made the relationship between total physical activity and preterm birth still could not be concluded was the use of various methods in measuring physical activity.4,11

The purpose of this study was to determine the relationship between physical activity intensity with preterm birth and to determine the relationship between physical activity type with preterm birth by using validated questionnaire: Kaiser Physical Activity Survey (KPAS)

\section{METHODS}

This study was case control with 127 subjects for each group which performed at Dr. Cipto Mangunkusumo Hospital (RSCM) and Karawang hospital from January 2017 to June 2017.

Sampling in this study was conducted with convenient sampling. Information was obtained by interviews that were taken from patients who entered into case groups and control groups. Case group was patient who underwent preterm birth at Dr. Cipto Mangunkusumo Hospital (RSCM) and RS Karawang from January 2017 to June 2017 who had met the inclusion criteria and did not fall into the exclusion criteria. Information from both groups was taken as long as the patient was still in the hospital until the number of sample targets was fulfilled. Information was obtained by conducting interviews using written questions which were contained in the KPAS questionnaire. Information on physical activity based on the questionnaire is the physical activity that was performed by pregnant women in the third trimester.

Inclusion criteria in this study include: women who conduct preterm birth (third trimester) in Dr. Cipto Mangunkusumo hospital and Karawang hospital period January 2017 to June 2017; willing to follow the study and fill out the completeness of informed consent.

Exclusion criteria in this study include : vaginal bleeding in second trimester and third trimester confirmed by history taking with a history of vaginal bleeding in $2^{\text {nd }}$ and $3^{\text {rd }}$ trimester that occurred more than one time; cervical incompetence based on history taking and or ultrasound examination and from anamnesis is obtained from the history of the outcome of conception in the second trimester without any pain, and or there is an ultrasound examination which shows the cervical abnormalities and or amnion bag funneling; multiple pregnancies which was confirmed based on patient's medical history after she had both in current pregnancy; the history of abortion in this pregnancy which was confirmed by history taking; sudden onset of trauma which was confirmed by history taking; hypertension, diabetes mellitus, preeclampsia.

\section{The KPAS Questionnaire}

The KPAS questionnaire had been validated in 54 female samples at Baystate Medical Center using a seven-day accelerometer measurement. The coefficient correlation used to measure reproducibility in KPAS has ranged between $r=0.76$ to 0.86 and Spearman's correlation coefficient between KPAS and 3 published cutting points for the accelerometer classification is ranged from $\mathrm{r}=0.49$ to 0.59 . 


\section{Statistical Analysis}

Statistical analysis was performed by using SPSS $20^{\circledR}$ software for the Windows ${ }^{\circledR}$ operating system. The analysis was done by multivariate analysis of the etiologic concept.

\section{RESULTS}

Characteristics of the subjects are presented in Table 1. In term birth, physical activity with moderate intensity is the highest level of physical activity intensity $(64.6 \%, \mathrm{n}=82)$, followed by physical activity with moderate intensity (22\%, $\mathrm{n}=28$ ), and the last was physical activity with vigorous intensity $(13.4 \%, \mathrm{n}=17)$. However, different result was found in preterm birth. In preterm birth, physical activity with light intensity was the most common physical intensity $(40.2 \%$, $\mathrm{n}=51$ ), followed by physical activity with vigorous intensity $(33.9 \%, n=43)$, and the last is physical activity with moderate intensity $(26 \%, n=33)$.

Table 1. Subject's Characteristics

\begin{tabular}{|c|c|c|c|c|c|c|}
\hline \multirow[t]{2}{*}{ Variable } & \multicolumn{2}{|c|}{ Preterm birth } & \multirow[t]{2}{*}{$\mathbf{p}$} & \multirow[t]{2}{*}{ or } & \multicolumn{2}{|c|}{$95 \% \mathrm{CI}$} \\
\hline & + n (\%) & - n (\%) & & & Min & Max \\
\hline Physical activity intensity & & & $<0.001$ & & & \\
\hline Light & $51(40.1)$ & $28(22.0)$ & $<0.001$ & 4.53 & 2.45 & 8.36 \\
\hline Moderate & $33(26.0)$ & $82(64.6)$ & Comparison & & & \\
\hline Vigorous & $43(33.9)$ & $17(13.4)$ & $<0.001$ & 6.29 & 3.15 & 12.55 \\
\hline Education & & & 0.002 & & & \\
\hline Elementary school & $17(13.4)$ & $6(4.7)$ & 0.443 & 5.67 & 0.43 & 74.38 \\
\hline Junior high school & $72(56.7)$ & $56(44.1)$ & 0.840 & 2.57 & 0.23 & 29.08 \\
\hline Senior high school & 37 (29.1) & $63(49.6)$ & 1.000 & 1.18 & 0.10 & 13.40 \\
\hline Bachelor & $1(0.8)$ & $2(1.6)$ & Comparison & & & \\
\hline \multicolumn{7}{|l|}{ Age } \\
\hline$\leq 35$ years old & $68(53.5)$ & $78(61.4)$ & 0.253 & 0.72 & 0.44 & 1.19 \\
\hline$>35$ years old & $59(46.5)$ & 49 (38.6) & Comparison & & & \\
\hline \multicolumn{7}{|l|}{ Vaginal discharge } \\
\hline Yes & $68(53.5)$ & $42(33.1)$ & 0.002 & 2.33 & 1.40 & 3.88 \\
\hline No & $59(46.5)$ & $85(66.9)$ & Comparison & & & \\
\hline \multicolumn{7}{|l|}{ Parity } \\
\hline Multiparity & $89(70.1)$ & $76(59.8)$ & 0.115 & 1.572 & 0.94 & 2.64 \\
\hline Nulliparity & $38(29.9)$ & $51(40.2)$ & Comparison & & & \\
\hline \multicolumn{7}{|l|}{ Closed pregnancy distance } \\
\hline Yes & $60(47.2)$ & $42(33.1)$ & 0.030 & 1.81 & 1.09 & 3.01 \\
\hline No & $67(52.8)$ & $85(66.9)$ & Comparison & & & \\
\hline \multicolumn{7}{|l|}{ History of preterm birth } \\
\hline Yes & $57(44.9)$ & $45(35.4)$ & 0.159 & 1.48 & 0.90 & 2.46 \\
\hline No & $70(55.1)$ & $82(64.6)$ & Comparison & & & \\
\hline \multicolumn{7}{|l|}{ Smoke } \\
\hline Yes & $21(16.5)$ & $20(15.7)$ & 1.000 & 1.06 & 0.54 & 2.07 \\
\hline No & $106(83.5)$ & $107(84.3)$ & Comparison & & & \\
\hline \multicolumn{7}{|l|}{ Alcohol } \\
\hline Yes & $1(0.8)$ & $0(0.0)$ & 1.000 & - & & \\
\hline No & $126(99.2)$ & $127(100.0)$ & Comparison & & & \\
\hline
\end{tabular}


Table 2 shows the relationship between physical activity intensity and preterm birth by controlling confounding variables which were: education level, vaginal discharge, parity, close pregnancy distance, and history of preterm birth. Physical activity with light intensity has OR 5.32 (95\% CI, 2.80-10.13; p= $<0.001$ ). Compared with moderate intensity. While physical activity with vigorous intensity has OR 6.65 (95\% CI, 3.28-13.46; $\mathrm{p}=<0.001$ ) compared with moderate intensity.
Table 3 shows the relationship between physical activity type and preterm labor. Adjusted OR of working in preterm birth was 3.19 (95\% CI, 1.62$6.28 ; \mathrm{p}=0.001$ ) and adjusted OR of exercise in preterm birth was 1.85 (95\% CI, 1.11-3.09; $\mathrm{p}=$ 0.017). Working condition was also associated with preterm birth, including: weight lifting (OR 5.16, 95\% CI,1.10-24.08; $\mathrm{p}=0.021$ ), walking (OR 3.57; 95\% CI,1.61-7.92; $\mathrm{p}=0.001$ ), sitting (OR 2.79; 95\% CI, 1.23-6.31; $\mathrm{p}=0.011$ ), and standing (OR 3.04; 95\% CI,1.40-6.59; $\mathrm{p}=0.003$ ).

Table 2. Relationship between Physical Activity Intensity with Preterm Birth

\begin{tabular}{lcccccccc}
\hline \hline & \multicolumn{2}{c}{ Preterm birth } & \multicolumn{2}{c}{ Unadjusted } & \multicolumn{3}{c}{ Adjusted } \\
& Positive n (\%) & Negative n (\%) & p & or & CI 95\% & p & or & CI 95\% \\
\hline Physical activity intensity & & & $<0.001$ & & & $<0.001$ & \\
Light & $51(40.2)$ & $28(22.0)$ & $<0.001$ & 4.53 & $2.45-8.36$ & $<0.001$ & 5.32 & $2.80-10.13$ \\
Moderate & $33(26.0)$ & $82(64.6)$ & & & & Comparison & & \\
Vigorous & $43(33.9)$ & $17(13.4)$ & $<0.001$ & 6.29 & $3.15-12.55$ & $<0.001$ & 6.65 & $3.28-13.46$ \\
\hline \hline
\end{tabular}

Table 3. Relationship between Physical Activity Intensity with Preterm Birth

\begin{tabular}{|c|c|c|c|c|c|c|}
\hline \multirow[t]{2}{*}{ Variable } & \multicolumn{2}{|c|}{ Preterm birth } & \multirow[t]{2}{*}{$\mathbf{p}$} & \multirow[t]{2}{*}{ or } & \multicolumn{2}{|c|}{$95 \%$ CI } \\
\hline & $+n(\%)$ & $-\mathbf{n}(\%)$ & & & Min & Max \\
\hline \multicolumn{7}{|l|}{ Working } \\
\hline Yes & $36(28.3)$ & $14(11.0)$ & 0.001 & 3.19 & 1.62 & 6.28 \\
\hline No & 91 (71.7) & $113(89.0)$ & & & & \\
\hline \multicolumn{7}{|l|}{ Exercise } \\
\hline No & $88(68.2)$ & $67(53.6)$ & 0.017 & 1.85 & 1.11 & 3.09 \\
\hline Yes & $41(31.8)$ & $58(46.4)$ & & & & \\
\hline \multicolumn{7}{|c|}{ Working condition Weightlifting } \\
\hline Always-often & $10(7.8)$ & $2(1.6)$ & 0.021 & 5.16 & 1.10 & 24.08 \\
\hline Never-seldom & $119(92.2)$ & $123(98.4)$ & & & & \\
\hline \multicolumn{7}{|l|}{ Walking } \\
\hline Always-often & 28 (21.7) & $9(7.2)$ & 0.001 & 3.57 & 1.61 & 7.92 \\
\hline Never-seldom & $101(78.3)$ & $116(92.8)$ & & & & \\
\hline \multicolumn{7}{|l|}{ Sitting } \\
\hline Always-often & $23(17.8)$ & $9(7.2)$ & 0.011 & 2.79 & 1.23 & 6.31 \\
\hline Never-seldom & $106(82.2)$ & $116(92.8)$ & & & & \\
\hline \multicolumn{7}{|l|}{ Standing } \\
\hline Always-often & $27(20.9)$ & $10(8.0)$ & 0.003 & 3.04 & 1.40 & 6.59 \\
\hline Never-seldom & $102(79.1)$ & $115(92)$ & & & & \\
\hline
\end{tabular}




\section{DISCUSSION}

In preterm birth, physical activity with light intensity was the most common physical intensity that was done by pregnant woman $(40.2 \%, \mathrm{n}=$ $51)$, followed by vigorous intensity (33.9\%, $\mathrm{n}=$ 43 ), and the last was physical activity with moderate intensity $(26 \%, \mathrm{n}=33)$. The results of this study were different from previous studies that most pregnant women would reduce their physical activity. In this study, the most frequent intensity level of physical activity was physical activity with moderate intensity, and vigorous intensity which was $78 \%$ of all term birth and subjects who performed moderate intensity and vigorous intensity in preterm birth were $59.9 \%$.

Based on the previous study it was found that only $15 \%$ of pregnant women who fulfill the recommendations of physical activity in pregnant women based on ACOG (2002). ${ }^{2}$ In addition, a study which was conducted by Bisson et al (2017) showed that there was a decrease in the intensity of physical activity of pregnant women starting from the first trimester to third-trimester pregnancy. ${ }^{12}$ In addition, in a study which was conducted by Santos et al. (2014) found that pregnant women who had no activity during pregnancy ranged from $64.5 \%$ to $91.5 \%$ and tended to increase in the third trimester of pregnancy. ${ }^{13}$ Similarly, Pereira et al. (2007) showed that the prevalence of inactive pregnant women increased from $12.6 \%$ at the time before pregnancy to $21.6 \%$ in the second trimester and did not change until 6 months after delivery. ${ }^{14}$ Based on the previous study, it could be seen that there were differences between the results of this study with research that was conducted previously. These differences can be influenced by differences in nutrients before pregnancy, socioeconomic environment, and socio-cultural environment. ${ }^{15}$

In this study, we found that adjusted OR of light intensity of physical activity in preterm birth was 5.32 (95\% CI, $2.80-10.13 ; \mathrm{p}=<0.001$ ) compared with moderate-intensity physical activity for preterm birth. The light intensity of physical activity was associated with preterm birth was caused by the association between light physical activity with gestational diabetes mellitus and preeclampsia which could lead to placental insufficiency and increased inflammatory cytokines leading to preterm birth. ${ }^{13,16}$
Adjusted OR of physical activity with severe intensity in preterm birth was 6.65 (95\% CI, 3.2813.46; $\mathrm{p}=<0.001$ ) compared with moderateintensity physical activity for preterm birth. This may be due to other confounding factors, such as nutrient status, and body weight that has not been controlled in this study. Therefore, further research is needed by controlling for confounding factors which were nutrition, and body weight. ${ }^{17,18}$

The strengths of the present study include: This study was conducted by using multivariate analysis so that confounding variables and interaction variables that may be associated with preterm birth can be controlled; this research used casecontrol as study design; this study used a validated KPAS questionnaire. Our study also has limitations, which in this study there was a possibility of overestimation of the intensity of physical activity, although the questionnaires used have used a validated questionnaire using accelerometry. To improve the accuracy in assessing the intensity of physical activity in pregnant women, the future study can be done accelerometry to know the intensity of physical activity accurately.

\section{REFERENCES}

1. Blencowe H, Cousens S, Oestergaard MZ, Chou D, Moller AB, Narwal R, et al. National, regional, and worldwide estimates of Premature birth rates in the year 2010 with time trends since 1990 for selected countries: a systematic analysis and implications. Lancet. 2012; 379(9832): 2162-72.

2. Lawn J, Gravett M, Nunes T, Rubens C, Stanton C. Global report on Premature birth and stillbirth (1 of 7): definitions, description of the burden and opportunities to improve data. BMC pregnancy and childbirth. 2010; 10(Suppl 1): S1.

3. Artal R, O'Toole M. Guidelines of the American College of Obstetricians and Gynecologists for exercise during pregnancy and the postpartum period. Br J Sports Med. 2003; 37(1): 6-12; discussion.

4. Domingues MR, Matijasevich A, Barros AJ. Physical activity and Premature birth: a literature review. Sports Med. 2009; 39(11): 961-75.

5. Nesbitt AE, Murphy RJ, O'Hagan KP. Effect of gestational stage on uterine artery blood flow during exercise in rabbits. J Applied Physiol. 2005; 99(6): 2159-65.

6. Feiner B, Weksler R, Ohel G, Degani S. The influence of maternal exercise on placental blood flow measured by Simultaneous Multigate Spectral Doppler Imaging (SM-SDI). Ultrasound Obstet Gynecol. 2000; 15(6): 498-501.

7. Kennelly MM, McCaffrey N, McLoughlin P, Lyons S, McKenna P. Fetal heart rate response to strenuous maternal exercise: not a predictor of fetal distress. Am J Obstet Gynecol. 2002; 187(3): 811-6.

8. Bergmann A, Zygmunt M. Running throughout pregnancy: effect on placental villous vascular volume and cell proliferation. Placenta. 2004; 25(8): 694-8. 
9. Clapp J. Influence of endurance exercise and diet on human placental development and fetal growth. Placenta. 2006; 27(6): 527-34.

10. Meher S, Duley L. Exercise or other physical activity for preventing pre-eclampsia and its complications. Cochrane Database Syst Rev. 2006: 2.

11. Harrison CL, Thompson RG, Teede HJ, Lombard CB. Measuring physical activity during pregnancy. Int J Behav Nutr Phys Act. 2011; 8: 19.

12. Bisson M, Croteau J, Guinhouya BC, Bujold E, Audibert F, Fraser WD, et al. Physical activity during pregnancy and infant's birth weight: results from the 3D Birth Cohort. BMJ Open Sport Exerc Med. 2017; 3(1): e000242.

13. Santos PC, Abreu S, Moreira C, Lopes D, Santos R, Alves O, et al. Impact of compliance with different guidelines on physical activity during pregnancy and perceived barriers to leisure physical activity. J Sports Sci. 2014; 32(14): 1398408.
14. Pereira MA, Rifas-Shiman SL, Kleinman KP, Rich-Edwards JW, Peterson KE, Gillman MW. Predictors of change in physical activity during and after pregnancy: Project Viva. Am J Prev Med. 2007 Apr; 32(4): 312-9.

15. Jarmuzek P, Wielgos M, Bomba-Opon D. Placental pathologic changes in gestational diabetes mellitus. Neuro Endocrinol Lett. 2015; 36(2): 101-5.

16. Cid M, Gonzalez M. Potential benefits of physical activity during pregnancy for the reduction of gestational diabetes prevalence and oxidative stress. Early Hum Dev. 2016; 94: 57-62.

17. Hackett GA, Cohen-Overbeek T, Campbell S. The effect of exercise on uteroplacental Doppler waveforms in normal and complicated pregnancies. Obstet Gynecol. 1992; 79(6): 919-23.

18. Chaddha V, Simchen MJ, Hornberger LK, Allen VM, Fallah S, Coates AL, et al. Fetal response to maternal exercise in pregnancies with uteroplacental insufficiency. Am J Obstet Gynecol. 2005; 193(3 Pt 2): 995-9. 